\title{
The Link between Financial System and Economics: Functions of the Financial System, Financial Crises, and Policy Implications
}

\author{
Serpil Kahraman Akdoğu ${ }^{1} \&$ Mehmet Umutlu \\ ${ }^{1}$ Department of Economics, Yaşar University, İzmir, Turkey \\ 2 Department of International Trade and Finance, Yaşar University, İzmir, Turkey \\ Correspondance: Mehmet Umutlu, Department of International Trade and Finance, Yaşar University, Bornova, \\ 35100, İzmir, Turkey. E-mail: 90-232-411-5195. E-mail: mehmet.umutlu@yasar.edu.tr \\ Received: July 16, 2014 \\ doi:10.5430/ijfr.v5n4p52 \\ Accepted: August 6, 2014 \\ Online Published: August 24, 2014 \\ URL: http://dx.doi.org/10.5430/ijfr.v5n4p52
}

\begin{abstract}
Financial system plays a key role in fostering economic growth by efficiently channelling the funds to investments. However, financial system is also considered as the source of instability especially during crisis periods. How to redesign financial system globally and nationally in order to achieve and maintain global financial stability without sacrificing the benefits of it is one of the priority issues for policy makers. This study surveys the benefits obtained from and damages caused by the financial system. This survey further overviews policy implications and suggestions about improving the financial system which help achieve long-term global financial stability.
\end{abstract}

Keywords: financial policy, financial crises, financial system, economic policy

\section{Introduction}

The role of finance for a well-functioning economy has been a discussion issue for a long time for financial economists. It is well documented that financial system plays a key role in fostering economic growth by efficiently channelling the funds to investments. Both theoretical and empirical works indicate a positive impact of financial sector development on economic growth. Besides the growth effect, there are some other important functions of the financial system for the economy. For instance, transporting cash backward or forward in time by borrowing or lending (Richard Brealey, Stewart Myers, and Alan Marcus, 2009), repackaging the risk by creating and selling assets with lesser risk to one party in order to buy assets with greater risk from another party (Jeff Madura, 2006), providing liquidity, lowering transactions costs, and providing up-to-date information about asset and commodity prices, interest rates and company values are some of the basic functions of the financial system.

However, on the other hand, financial system is also blamed for being a source of fragility and instability especially during crises periods. It is argued that liability risk and agency problems in financial markets can cause bank runs and trigger financial fragility (Thorsten Beck, 2012). The fragility in the banking system avoids the efficient channelling of funds to profitable investment projects, blocking the economic growth and increasing the unemployment rates. Moreover, it is observed that asset prices are very sensitive to unfavourable market conditions and high volatility in asset prices is observed in stock exchanges during crises periods. High volatility in stock exchanges has negative implications for investors such as an increase in the cost of capital and an increase in the number of stocks in a portfolio for efficient diversification (Mehmet Umutlu, Levent Akdeniz, Aslihan Altay Salih, 2013).

Because of the critical influences of finance on economy, it is not surprising that redesigning the financial structure to avoid financial fragility and instability is one of the main focuses of interest for the policy makers gathering in Group of Twenty (G20) meetings. One of the missions of G20 is to produce policies and regulatory reforms to construct a stronger financial framework for a long-term global financial stability. For this purpose, several summits and conferences are organized to facilitate the exchange of ideas among finance ministers and financial policy makers. Some structural and regulatory reforms in the financial system are discussed and suggested for a well-functioning economy. This survey study not only aims to overview the suggested and or implemented policies and regulatory reforms to redesign the financial structure to minimize its destabilising effects but also summarises the role of financial system for the economy by comparing the benefits obtained from and damages caused by the 
financial system. Whilst basic functions fulfilled by the financial system are examined as the main benefits to firms and households, severe socio-economic consequences of financial crises are discussed as the damages.

The remainder of the paper is organized as follows. The next section defines the structure of the financial system and its functions including the pivotal effect of finance on economy, the growth effect. The third section explains the risks that may be brought by the financial system. In the forth section, some implemented or suggested regulatory reforms and policies are overviewed. The last section concludes the paper.

\section{The Structure of Financial System and Its Functions}

Financial system brings together the excess fund owners (savers) seeking to make their money more and investors lacking funds (spenders) with profitable investment projects as outlined in Figure 1. The basic economic function of financial system is to channel funds from savers to spenders. But why this link between savers and spenders is so important for the economy? For spenders with profitable investment opportunities but without enough funds to finance their projects, the ability to borrow from the excess funds owners with no productive projects through financial system avoids spenders to miss profitable projects. Additionally, because borrowers will not search for individual excess fund owners willing to lend and just obtain the fund from the capital markets, they will also not incur costs associated with searching available lenders.

Thus, by using several means of the financial system, investors with shortage of funds are able to access to cheaper financing for their projects, increasing their profitability. On the other hand, excess fund owners who are willing to lend also benefit from the financial system. They increase their wealth by obtaining some part of the profit of the most attractive projects that are made available in the capital markets in the form of interest or partial ownership. Thus, both savers and borrowers are better off and the resources are allocated efficiently in a world with financial markets.

Corporations and government bodies are generally the major group of spenders with attractive investment opportunities although households can also be spenders. Oppositely, savers are primarily the households but any corporations and government bodies can save as well. The flow of savings to investment in a public corporation can be established through financial markets, financial intermediaries and financial institutions. The savings from households flow to corporations to be used in real investments directly through financial markets or indirectly through financial intermediaries. In direct finance, savers lend funds directly to borrowers in exchange of securities which are claims on the borrowers' future income or assets (Frederic S. Mishkin, 2006). In indirect finance, financial intermediaries accept deposits from savers and then lend these raised funds to borrowers. So a financial intermediary is a hub between savings and real investment. The existence of well-functioning financial system will facilitate the transfer of funds in a cost-effective way, encouraging the savers to save more and spenders to invest more. The overall result is the increased total saving and total investment in the economy (William L. Megginson, 1997).

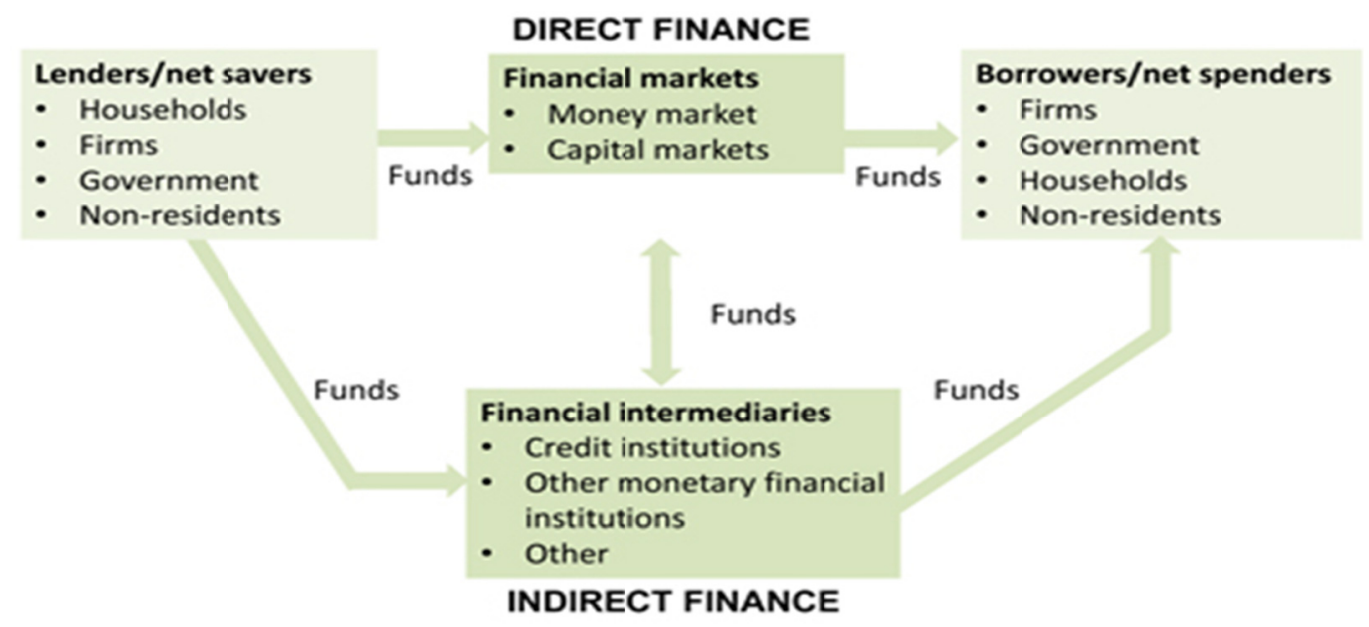

Figure 1. The structure of financial system

Source: European Central Bank (ECB). 2013. "Financial Structure". 
After having explained this, we next turn to other complementary functions of the financial system which are very important and beneficial as well. First of all, financial system allows transporting cash backward or forward in time by borrowing or lending, respectively (Brealey et al., 2009). For instance, anyone or any firm lacking funds for immediate consumption or investment now but has good prospects about future savings can transport the future income to today by borrowing from the means of financial system. Conversely, current excess of funds with no beneficial or productive usage can be translated to increased future funds through lending mechanism. Secondly, the financial system repackages the risk by creating and selling assets with lesser risk to one party in order to buy assets with greater risk from another party (Madura, 2006). Financial instruments such as options, futures, forward contracts, insurance policies and the diversification ability provided in the financial system allow for risk sharing. Thirdly, financial system provides liquidity through secondary markets and lower transactions costs. Moreover, it provides commodity price, interest rate and company value information which reflect the collective judgement of market participants and professionals about the prospects of these financial assets.

Finally, and maybe the most importantly, there is evidence that a well-functioning financial system leads to economic growth. The role of finance in economic growth attracted the attention of many researchers in the last few decades and a large body of literature examines the link between finance and economic growth (See Beck, 2012 for an extensive survey). There is abundant theoretical discussion and empirical evidence that well established financial system plays a critical role in fostering economic growth (see Ross Levine (2005) for a survey) especially for lowand middle-income countries (Felix Rioja and Neven Valev, 2004). It is also documented that the link between finance and growth is not just a correlation and the causality runs from finance to economic growth (Ross Levine, Norman Loayza, and Thorsten Beck, 2000). After the documentation of the positive relationship between finance and growth, researchers investigate the channels through which finance stimulates economic growth. Thorsten Beck, Ross Levine, and Norman V. Loayza (2010) show that finance fosters economic growth mainly through increasing productivity growth and improving resource allocation rather than through pure capital accumulation This finding helps explain why the positive finance and growth relationship is more pronounced for low- and middle-income countries. Finance helps low- and middle-income countries reach the productivity frontier (Rioja and Valev, 2004) but it does not have a growth effect for high-income countries because the productivity frontier is already met in these countries (Philippe Aghion, Peter Howitt, and David Mayer-Foulkes, 2005). Jean-Louis Arcand, Enrico Berkes, and Ugo Panizza (2012) showed that this relation can be even negative for high income countries. In summary, a positive relation between finance and economic growth beyond a pure correlation is documented in the literature. Cross-country studies show that this relation is not homogenous and it holds strongly for low- and middle-income countries, suggesting that financial system plays a vital role in achieving the economic growth especially in emerging economies.

So far, we explore the benefits of the financial system for the economy. But does financial system brings only benefits to the economy? Are there any costs associated with the financial system to obtain these benefits? The next section tries to shed light on these issues.

\section{Risks Brought by Financial Markets: Financial Instability and Fragility}

Although financial system provides many benefits to the economy as explained in the previous section, these benefits come at some costs. The mains costs that are thought to be brought by the financial system are crises accompanied with financial instability and fragility. Beck (2012) discusses the liability risk and agency problems in the financial markets as the main sources of financial fragility. While liability risk stems from the maturity mismatch between assets and liabilities, agency problems emerge because of information asymmetry between banks and depositors. It is argued that both the liability risk and agency problems can lead to bank runs and collapses, causing financial fragility.

In other financial markets such as stock exchanges, instability and high volatility are typically observed during crises periods. Increases in the cost of capital and in the number of stocks in a portfolio to achieve a given level of diversification as a result of increased volatility are some of the costs discussed in the literature (John Campbell, Martin Lettau, Burton Malkiel, Yexiao Xu, 2001; Umutlu et al., 2013). The policy makers search the ways of redesigning the financial system to eliminate or lessen the severe effects of crises and the associated costs without sacrificing the benefits of the financial system. To do so, good understanding of the crisis and its sources is necessary. Therefore the next subsection addresses these issues.

\subsection{Defining Financial Crisis and Its Sources}

Financial crises have become a worldwide phenomenon after 1980s. A financial crisis can drive the economy away from the equilibrium so that financial markets are no longer able to efficiently channel funds to most productive investment opportunities (Mishkin, 1992). Financial crisis can be defined as the following: 
"Financial Crisis is a disruption to financial markets in which adverse selection and moral hazard problems become much worse, so that financial markets are unable to efficiently channel funds to those who have the most productive investment opportunities." (Mishkin, 1996).

There are several other views trying to explain the financial crises. The New Keynesian view is based on the "Asymmetric Information" framework and has been constructed to explain financial crises mostly in the developed country context. This approach is based on the Nobel prized article entitled "The Market for "Lemons" Quality, Uncertainty and Market Mechanism" by George A. Akerlof (2002). A lemon problem occurs when lenders have trouble in determining risk level of credits. Parties are said to be asymmetrically informed when one party has less or more information than the other party. According to Mishkin (1996), financial crisis is the disruption of financial markets through deepening of adverse selection and moral hazard problems. Mishkin (2001) also noted that there are four types of problems causing financial crises; deterioration of financial sector, deterioration of nonfinancial balance sheets due to stock market declines, increase in uncertainty and increase in interest rates. As can be seen in Figure 2, banking sector as an important player in financial intermediation is the main source of a financial crisis. Asymmetric information framework is critical to bank panic. In a bank panic, depositors try to withdraw all their deposits which then causes bank to fail. In addition to causing a liquidity problem, a bank panic may also lead to increase interest rates. The result is that a bank panic reduces the investment level and thus economic activity declines. Moreover, unanticipated declines in the aggregate price level also causes the net worth of firms in real terms to decline and moral hazard and adverse selection problems become worsen. The net result is that a decline in aggregate economic activity (Mishkin, 1992).

The asymmetric information framework for analysing financial crisis suggests that there is a strong rationale for an international lender of last resort mechanism to cope financial distress. In emerging market economies, central banks are less likely to have the ability to promote recovery from a financial crisis with that mechanism. Furthermore, many of these economies have much of their debt denominated in foreign currency and also have high inflation rates. For these reasons, central banks cannot use expansionary monetary policy to reduce financial fragility. So, an expansionary monetary policy with the above institutional framework results in a deterioration in firms' and banks' balance sheets and lowers the net worth. Thus, adverse selection and moral hazard problems may arise in financial markets followed by a financial crisis (Mishkin, 1999).

Monetarist view as another strand of view trying to explain financial crises links financial crises only with banking failures because these failures are seen as major source of contractions in the money supply. According to Monetarists, sharp decline in asset prices is not an identifying event for a financial crisis as far as it does not create a potential for bank panic (Mishkin, 1990). This approach also emphasizes that international transmission of financial crises can occur due to disruption in short-term capital flows, leading a sharp decline in money supply and then in the overall economic activity. They advocate the role of central bank as a lender of last resort for the stability of the financial system. Moreover, they support the view that Central Banks have to conduct open market operations to provide liquidity needed by the banking system.

Oppositely, Charles P. Kindleberger and Hyman Minsky (1992) argue the Post Keynesian "Debt and Financial Instability Approach". This approach suggests that financial crisis may occur when the government budget deficit will have to be financed by the money supply. In this view, financial crises can be characterized as sharp declines in asset prices, market failure, disinflations or deflations, disruptions in foreign exchange (Mishkin, 1992). Kindleberger and Minsky (1992) support the government intervention because they think that crash does not lead to panic in money market or bank runs in financial system as far as Federal Reserve plays an effective role. Maybe the most important view of this approach is the Minsky Hypothesis. Minsky (1992) developed the "Financial Instability Hypothesis" (FIH) or also known as the Minsky Hypothesis. In his model, even if an economy is in equilibrium, optimist borrowers and lenders believe that most investments will be successful and thus more external funds will be accessible. This will trigger speculative bubbles in asset prices and debts exceeding revenues. As the bubble bursts, financial fragility and crisis will emerge. Once a crisis occurs, the most important adjustment policies are: 1) currency devaluation, 2) restrictive monetary and fiscal policies, 3) imposing trade barriers, 4) tightening exchange controls (Shale Horowitz and Uk Heo, 2001).

Finally, there is another line of literature focusing on currency crises. Currency crises are defined as an unexpected situation characterized by sudden reserve losses and capital flights. Currency crises can be classified into two groups: Exchange rate crises and balance of payment crises. Exchange rate crises are observed in fixed exchange rate regime economies as a result of abrupt speculative attacks of economic agents trying to exchange domestic currency for foreign currency until the monetary authorities are no longer able to maintain the exchange parity. Although balance 
of payment crisis has attracted little theoretical attention, usually exchange rate crisis predates balance of payment crisis. When the central bank's foreign reserves and policy instruments are not adequate to prevent the domestic currency from appreciation or depreciation, balance of payment crisis occurs. To improve the deterioration in balance of payment, Central Bank allows to devalue the currency and exchange rate to float (Paul Krugman, 1999).

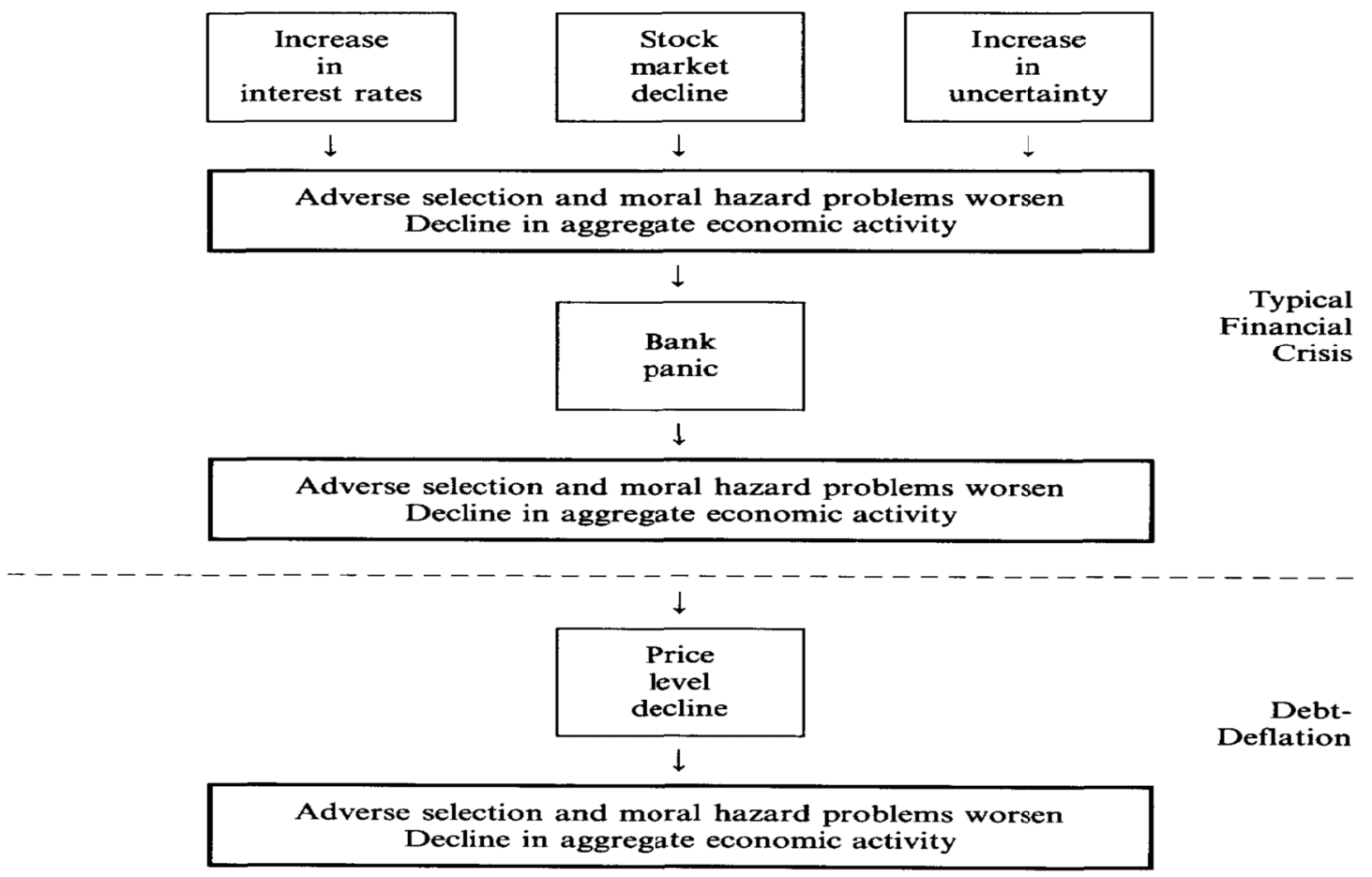

Figure 2. Sequence of events in a financial crisis

Source: F.S. Mishkin. 1992. "Anatomy of a Financial Crisis".

\subsection{The Recent Eurozone Sovereign Debt Crisis}

The Eurozone Sovereign debt Crisis was a "financial fragility" period, beginning with the default of Lehman Brothers in September 2008. This event leaded to increasing uncertainty and decreasing trust in financial markets. The sovereign debt holders began to fly to relatively liquid and safe alternative sovereign bond markets. During the crisis, foreign capital was more mobile than domestic capital. Due to banking distress "cut and run behaviour" of foreign capital arose. That is, if foreigner investors fear that the central bank of country has insufficient reserves, banking distress spreads to the foreign clients and they respond to the crises by cutting further lending (Thorsten Janus and Daniel Riera-Crichton, 2012). In the recent Eurozone crisis, the important role of the adoption of the common currency is noted. Although the common currency led to convergence in interest rates, rising capital inflows, real estate bubble and higher growth in periphery countries, it also caused loss of competitiveness, poor export performance and an increased budget deficit with the burst of the real estate bubble (Justin Lin and Volker Treichel, 2012). During the Eurozone crisis, investors focused on the solvency issues related to default probability and fragility in financial markets (Patrick Bolton and Olivier Jeanne, 2011). This had severe impact on the financial markets in the European Union (EU) countries and the first effects were observed in Greece. Later on the crisis spread to the other peripheral European countries such as Portugal, Ireland, Italy and Spain (PIIGS). At the end of 2009, the fiscal deficit in PIIGS increased rapidly after the revelation of the misconduct in Greek public accounts as can be seen in Table 1. Huge debt levels are seen as the result of unsustainable macroeconomic imbalances (Marta Gomez-Puig and Simon Sosville Rivero, 2011).

The size of the deterioration of public finance was considerable during the crisis and all PIIGS countries had accumulated high levels of foreign debt. It is noteworthy that the limit for debt to Gross Domestic Product (GDP) ratio is \%60 according to euro convergence criteria. As it is evident in Table.1, Portugal, Ireland, and Greece's GDP is only \%1.4 of the total EU's GDP in 2011. A public debt to GDP ratio of \%166 in Greece and a foreign debt to GDP ratio of \%1093 in Ireland are the highest levels in Eurozone in the relevant categories. In Ireland, the increasing probability of default risk related to the domestic housing boom mostly financed by foreign borrowers played a key 
role during crisis. However, in Ireland the crisis originated in the banking sector then turned to the sovereign debt crisis. In contrast to Greece, Portugal, Spain and Italy, the main characteristics of the sovereign debt crisis in Ireland is the high foreign debt of the private sector. Of course each country has its own country-specific factors that affect the degree of crisis. For instance, it is argued that low size of the public expenditures, the adoption of a procyclical expansionary fiscal policy, the years before the crisis, and the lack of a correct coordination between the Spanish fiscal policy and the ECB's monetary policy are the key elements for the deep and long economic crisis in Spain (Jesus Ferreiro, Carmen Gomez, Felipe Serrano, 2013). In Portugal, high and increasing levels of indebtedness, low and decreasing levels of saving, the existence of a dualist labour market, poor public budget governance and lack of transparency and accountability are seen as the major driving forces for the economic crisis (Joao Sousa Andrade and Adelaide Duarte, 2011).

Table 1. GDP and debt in selected EU and Non-EU countries (2011)

\begin{tabular}{lcccccc}
\hline & $\begin{array}{c}\text { GDP } \\
\text { (trillion } € \text { ) }\end{array}$ & $\begin{array}{c}\text { Foreign Debt } \\
\text { (trillion } € \text { ) }\end{array}$ & $\begin{array}{l}\text { Foreign Debt } \\
\text { / GDP }(\%)\end{array}$ & $\begin{array}{l}\text { Foreign Debt } \\
\text { per person }(€)\end{array}$ & $\begin{array}{c}\text { Public Debt } \\
\text { (trillion } € \text { ) }\end{array}$ & $\begin{array}{c}\text { Public Debt / } \\
\text { GDP (\%) }\end{array}$ \\
\hline France & 1.8 & 4.2 & 235 & 66,508 & 1.6 & 87 \\
\hline Spain & 0.7 & 1.9 & 284 & 41,366 & 0.5 & 67 \\
\hline Portugal & 0.2 & 0.4 & 251 & 38,081 & 0.2 & 106 \\
\hline Italy & 1.2 & 2.0 & 163 & 32,875 & 1.5 & 121 \\
\hline Ireland & 0.2 & 1.7 & 1093 & 390,969 & 0.2 & 109 \\
\hline Greece & 0.2 & 0.4 & 252 & 38,073 & 0.3 & 166 \\
\hline Germany & 2.4 & 4.2 & 176 & 50,659 & 2.0 & 83 \\
\hline Eurozone & 6.7 & 14.8 & 221 & 53,202 & 6.2 & 93 \\
\hline UK & 1.7 & 7.3 & 436 & 117,580 & 1.4 & 81 \\
\hline USA & 10.8 & 10.9 & 101 & 35,156 & 10.8 & 100 \\
\hline Japan & 4.1 & 2.0 & 50 & 15,934 & 9.6 & 233 \\
\hline
\end{tabular}

Source: Finance Invest.

Table 2. 2011 Eurozone debt matrix (bn euro)

\begin{tabular}{ccccccccccc}
\hline Countries & Germany & UK & US & France & Spain & Portugal & Italy & Ireland & Greece & Japan \\
\hline Germany & & 141.1 & 174.4 & 205.8 & 0 & 0 & 202.7 & 0 & 0 & 108.3 \\
\hline UK & 379.3 & & 578.6 & 209.9 & 316.6 & 0 & 0 & 113.5 & 0 & 122.7 \\
\hline US & 414.5 & 834.5 & & 440.2 & 170.5 & 0 & 0 & 0 & 0 & 835.2 \\
\hline France & 123.5 & 227 & 202.1 & & 0 & 0 & 37.6 & 0 & 0 & 79.8 \\
\hline Spain & 131.7 & 74.9 & 49.6 & 112 & & 19.7 & 22.3 & 0 & 0 & 20 \\
\hline Portugal & 26.6 & 19.9 & 3.9 & 19.1 & 65.7 & & 2.9 & 0 & 0 & 0 \\
\hline Italy & 120 & 54.7 & 34.8 & 309 & 29.5 & 0 & & 0 & 0 & 32.8 \\
\hline Ireland & 82 & 104.5 & 39.8 & 23.8 & 0 & 0 & 0 & & 0 & 15.4 \\
\hline Greece & 15.9 & 9.4 & 6.2 & 41.4 & 0 & 7.5 & 2.8 & 0 & & 0 \\
\hline Japan & 42.5 & 101.8 & 244.8 & 107.7 & 0 & 0 & 0 & 0 & 0 & \\
\hline
\end{tabular}

Source: British Broad Casting Corporation (BBC) News.2011. "Eurozone debt web: Who owes what to whom?"

The debt matrix presented in Table 2 shows the debt levels in the Eurozone as well as in the other big world economies, such as Japan and USA. The peripheral EU countries, such as Greece, Portugal, Spain, Italy and Ireland are heavily indebted to other Eurozone countries. So any default risk in one county could directly contagion to its creditor countries. Therefore, EU member governments and IMF were setting up a lending mechanism for Greece and other peripheral countries to avoid spreading the crisis. Additionally, the main global actors, US, Japan, and Germany also hold large amount of government bonds from the financially distressed countries. Thus, the international risk factor also has come into focus.

Figure 3 exhibits the debts of several countries as a ratio to their GDPs in 2007 and in 2011. It is seen that advance economies and many Euro Zone members increased their Debt/GDP ratio considerably in 2011 as compared to that in 2007. Beyond increasing their debt levels, some countries such France, US, Portugal, Ireland, Island, Italy, China 
and Japan are heavily indebted with debt/GDP ratios larger than $100 \%$ in 2011 . There were only a few countries with debt/GDP ratio exceeding $100 \%$ before the crisis. An overview of Debt/GDP ratio by country grouping as shown in Figure 4 reveals that during the same period, emerging and developing economies in Asia, Latin America, Middle East and North Africa preserved their Debt/GDP ratios at the beginning of the financial crisis. This observation suggests that in contrast to advance economies, emerging and developing economies did not change their lending behavior during the crisis period probably because they did not need additional funding or they were able to raise money without lending. This is consistent with the fact that many emerging economies performed well during the crisis. However, high debt levels in advance economies lead to severe socio-economic consequences such as cuts in social benefits and fiscal consolidation programs.

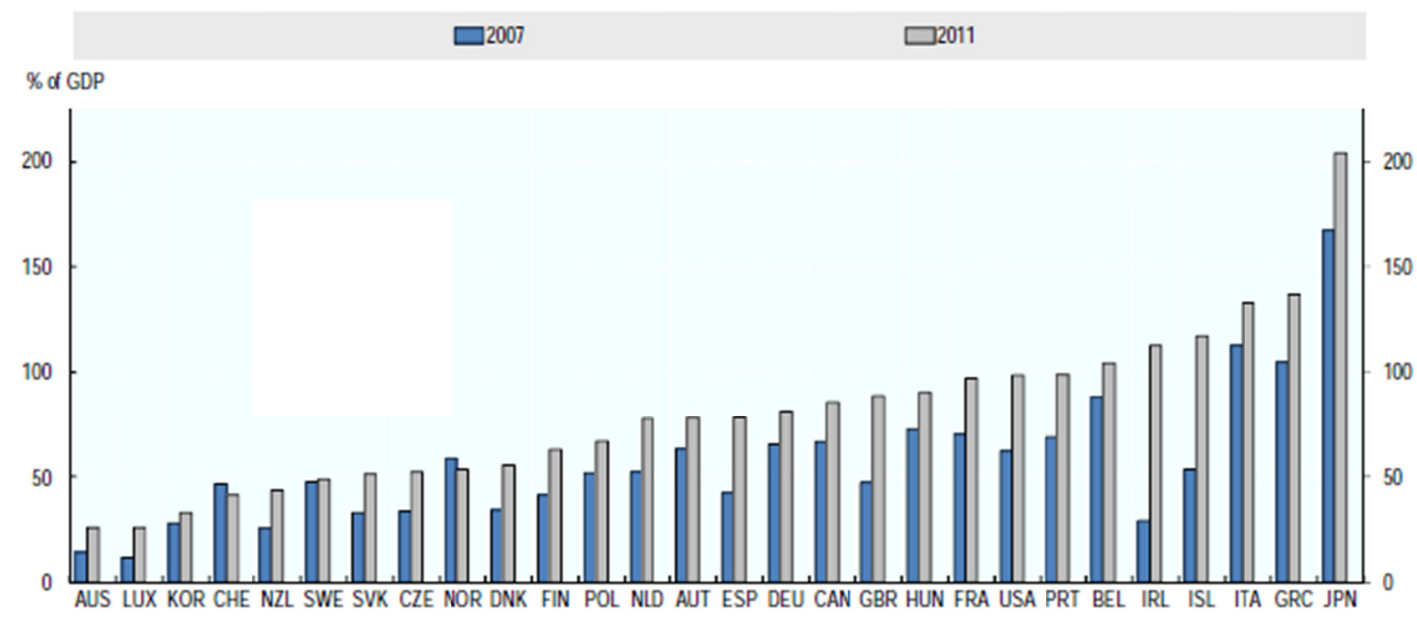

Figure 3. Gross government financial liabilities

Source: Organisation for Economic Co-operation and Development (OECD).2012.“Fiscal Consolidation: How much, how fast and by what means?"

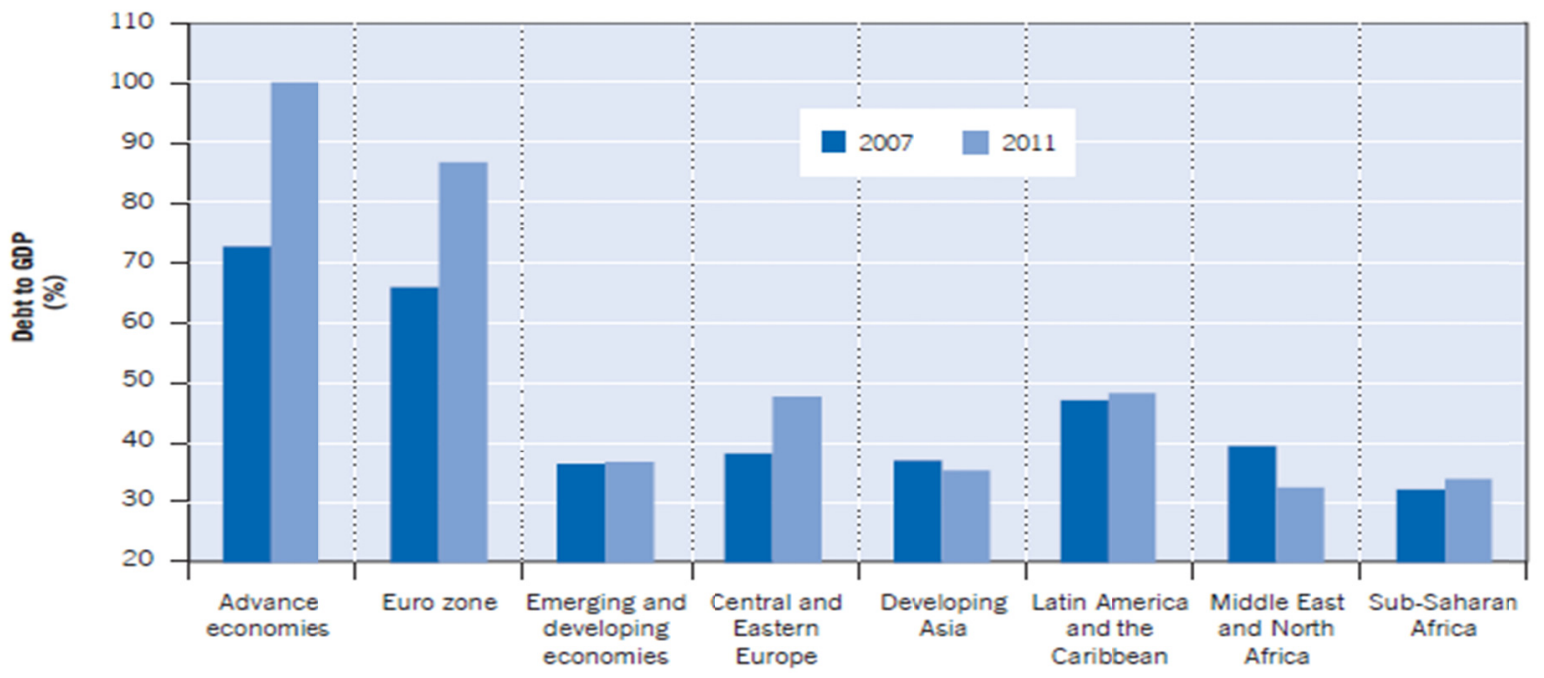

Figure 4. Debt to GDP by country grouping 2007 and 2011

Source: International Labour Organization (ILO).2011."Building a sustainable job rich recovery".

Figure 5 presents the percentage of countries that have introduced cuts in social benefits since 2008. Not surprisingly, the largest cuts were put in use in about $80 \%$ of EU 27 countries and $65 \%$ of advance economies. Only less than $30 \%$ of emerging economies cut the social benefits. A detailed decomposition of fiscal tightening is presented in Figure 6 for G20 and the EU countries. Many countries implemented cuts in social security and public sector spending while increasing taxes. As a result of severe socio-economic consequences of these tightening measures, protests against integration within Europe are increasing and the opponents of globalization are rising in the euro area. Moreover, the 
sustainability of a well-functioning financial system is now being questioned because financial markets have shrunk extremely.

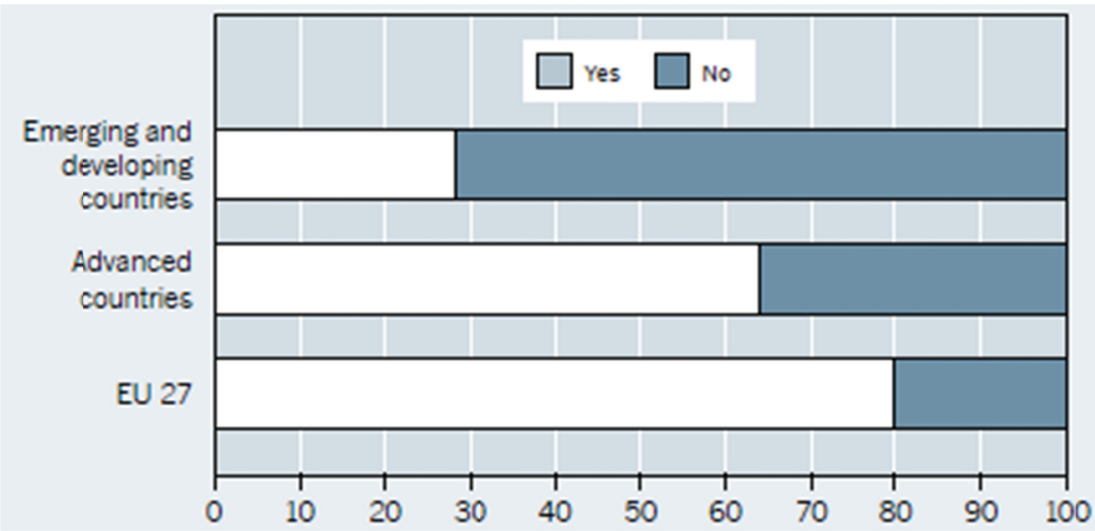

Figure 5. Percentage of countries that have introduced cuts in social benefits since 2008

Source: ILO. 2012. "World of Work Report: Better jobs for a better economy".

\begin{tabular}{|c|c|c|c|c|}
\hline & $\begin{array}{l}\text { Effective increase } \\
\text { in taxation }\end{array}$ & $\begin{array}{l}\text { Effective cuts } \\
\text { in social security }\end{array}$ & $\begin{array}{l}\text { Public sector } \\
\text { cuts }\end{array}$ & $\begin{array}{c}\text { Other } \\
\text { spending cuts }\end{array}$ \\
\hline Australia & $x$ & & & \\
\hline Canada & & & $\times$ & $x$ \\
\hline Denmark & $x$ & $x$ & $x$ & $x$ \\
\hline Estonia & $x$ & $x$ & & $\times$ \\
\hline France & $\times$ & $\times$ & & \\
\hline Germany & $x$ & $\times$ & & $\times$ \\
\hline Greece & $\times$ & $\times$ & $\times$ & $\times$ \\
\hline Hungary & $\times$ & & $\times$ & \\
\hline India & $\mathrm{x}$ & $\times$ & & \\
\hline Indonesia & $x$ & & & \\
\hline Ireland & $x$ & $\times$ & $\times$ & \\
\hline Italy & & $x$ & $\times$ & \\
\hline Latvia & $x$ & $x$ & $\times$ & \\
\hline Lithuania & $x$ & $\times$ & $x$ & $x$ \\
\hline Netherlands & & $x$ & $x$ & $x$ \\
\hline Portugal & $x$ & & $x$ & $x$ \\
\hline Romania & & $\times$ & $x$ & \\
\hline Slovenia & & & & $x$ \\
\hline Spain & $x$ & $\times$ & $\times$ & $x$ \\
\hline United Kingdom & & $\times$ & $\times$ & $\times$ \\
\hline
\end{tabular}

Figure 6. Overview of fiscal consolidation programmes in G20 and the EU

Source: ILO.2010. "World of Work Report: From one crisis to the next."

Note: The table indicates planned or actually implemented consolidation measures in four main areas up to 2012. Tax measure includes increases of excise taxes, personal and capital income taxes and taxes on financial services. Cuts in social security cover measures related to public pension, health care, education and unemployment benefit systems. Public sector cuts include wage cuts and/or reduction in public sector employment. Other spending cuts include cuts in infrastructure, military spending and foreign aid.

\section{Redesigning the Financial System}

Due to the severe socio-economic consequences of the financial crises, policy makers especially in G-20 work on how to change the structure of the financial system so that financial crises are avoided or their damaging effects are kept at minimum to the possible extent. However, this is not an easy task. Ross Levine (2012) points out a failure of financial regulation due to absence of an informed, expertly staffed, and independent institution that evaluates 
financial regulation from the public's perspective. Successful monetary policy requires successful regulation and prudential supervision of the financial system (Mishkin, 1996). In the long run, all policy makers agree that financial stability with fiscal discipline is the highest priority to reduce market risks. Recent financial crises have highlighted the need for structural and regulatory reforms. In this section, some reforms and regulations which are implemented or suggested in the literature are reviewed.

Given the fact that well-functioning financial markets lead to efficient allocation of capital which in turn fosters economic growth, policy makers and central banks focus on the well-being of the financial system to ensure sustainable growth. Financial policy makers in G-20 come up with various measures to improve a malfunctioning financial system and to support financial stability and economic growth during the financial crisis. Although the reforms had some positive impacts on economy, financial fragility is still a hot issue for many countries.

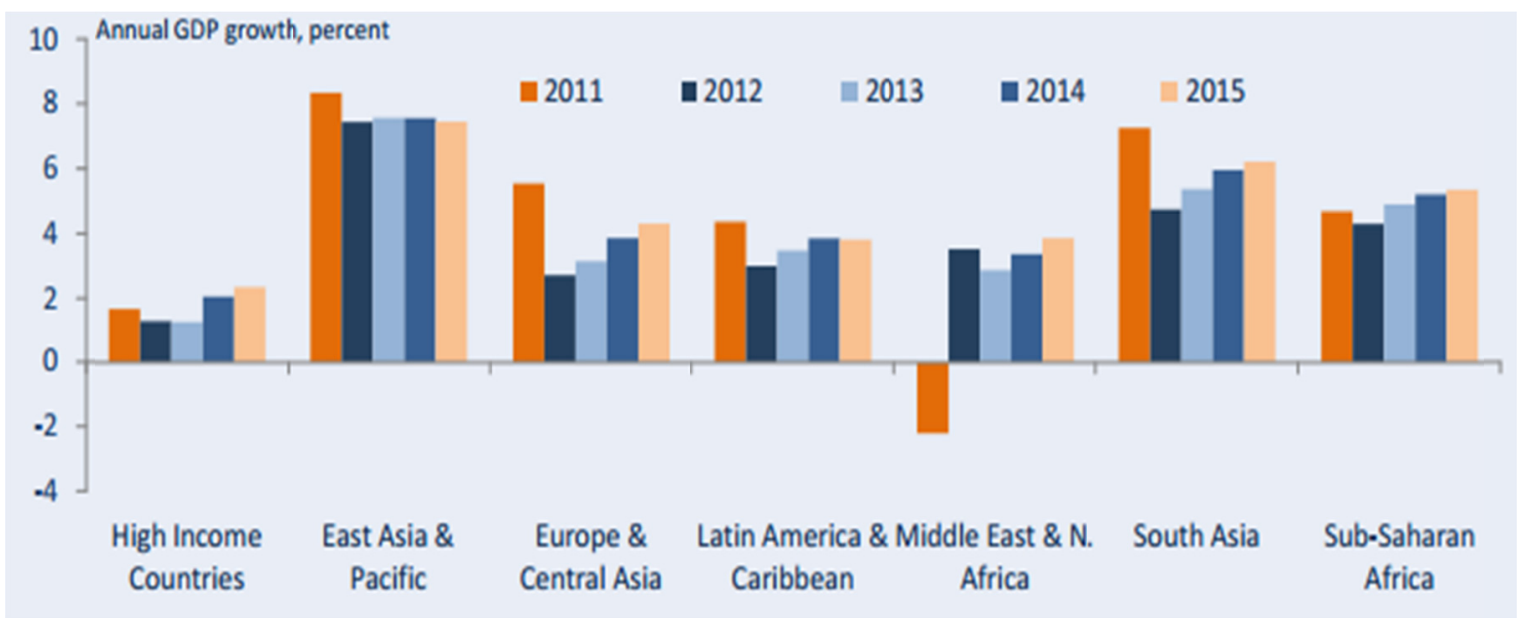

Figure 7. GDP growth estimates and projections, 2011-2015 (annual \% change)

Source: World Bank (WB). 2013. "Less Volatile But Slower Growth".

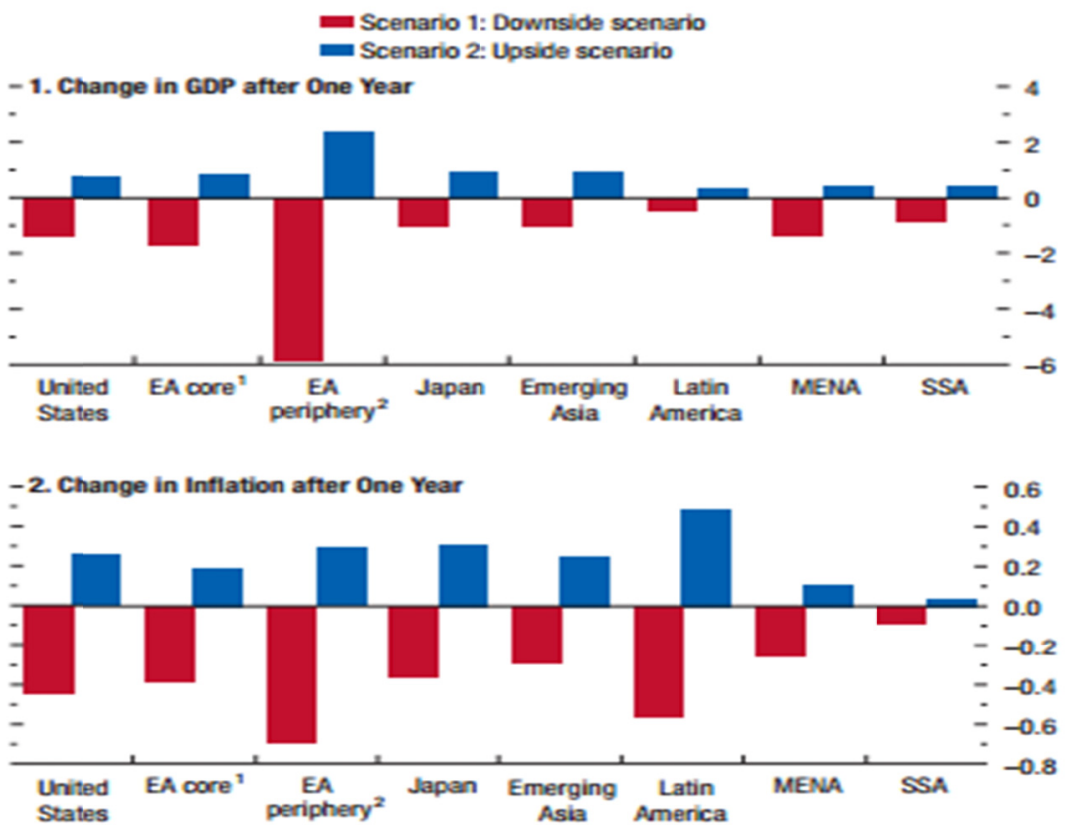

Figure 8. Downside and upside scenarios (percent or percentage point deviation from WEO baseline)

Source: International Monetary Fund (IMF). 2012. "Coping with High Debt and Sluggish Growth".

Note: EA=Euro area, MENA=Middle East and North Africa, SSA=Sub-Saharan Africa 
1) Core countries are: Austria, Cyprus, Belgium, Estonia, Finland, France, Germany, Luxembourg, Malta, Netherlands, Slovak Republic and Slovenia.

2) Periphery countries are: Greece, Portugal, Spain, Ireland, Italy.

Figure 7 suggests that the recent trend and the projections about GDP growth are not very brilliant. Especially in the high income countries, the very low levels of GDP growth are observed and the projections indicate that low levels of GDP growth are expected in the short run. Although the GDP growth rates are relatively higher for the rest of the world, it is not anticipated that the growth rates in 2011 will be achieved in the forthcoming years. This suggests a very slow recovery or perhaps even further downside risks for the global economy during 2014 and 2015.

The most immediate downside risks are the possibility of a longer growth slowdown in many economies (See Figure 8 for expected changes in GDP for several countries and regions under downside scenario) and excessive fiscal tightening which may lead to turmoil in global bond and currency markets (IMF, 2012). Global growth slowed more than expected since the fourth quarter of 2011, as a result of rise in sovereign yields and the impact of fiscal consolidation in euro area. By contrast, growth in the advanced economies as in Japan and US was stronger than anticipated due to stabilizing oil prices by the first quarter of 2011. So, the oil prices remain the main source of downside risks.

Another downside risk relates to the insufficient progress in fiscal consolidation plans in the USA and Japan. The G-20 Finance Ministers and Central Bank Governors highlighted these downside risks that need to be addressed in the reform process raised at the meeting of the European economic governance in Paris 2011. They first, made progress on action plan which is based on Cannes Summit 2011, including a set of measures for sustainable and balanced growth. According to this plan, it is stated that all economies will undertake further structural reforms to support sustainable growth, in the face of downside risks, inflationary pressures, and volatile capital flows. It is clear that the structural reforms should be designed to meet the need for growth-friendly fiscal consolidation.

\subsection{Economic Reforms}

The governments' macroeconomic programmes include product market reforms and labour market reforms. Labour market reforms' objective is to get improvements in job-search options, wage agreements, employment protection to living standards and employment (Organization for Economic Cooperation and Development, 2011).The global unemployment rate is expected to remain at around 6\% with over 190 million of total unemployment until 2017 as can be seen in Figure 9. The change in global unemployment and global GDP growth rate are shown in Figure 10. Not surprisingly, a negative correlation between the two is observed. The projections in Figure 10 point out that change in total unemployment is expected to be positive during the 2012-2017 period both under the normal and downside scenarios, suggesting a net increase in global unemployment. As a result, employment level is not expected to recover to pre-crisis levels.

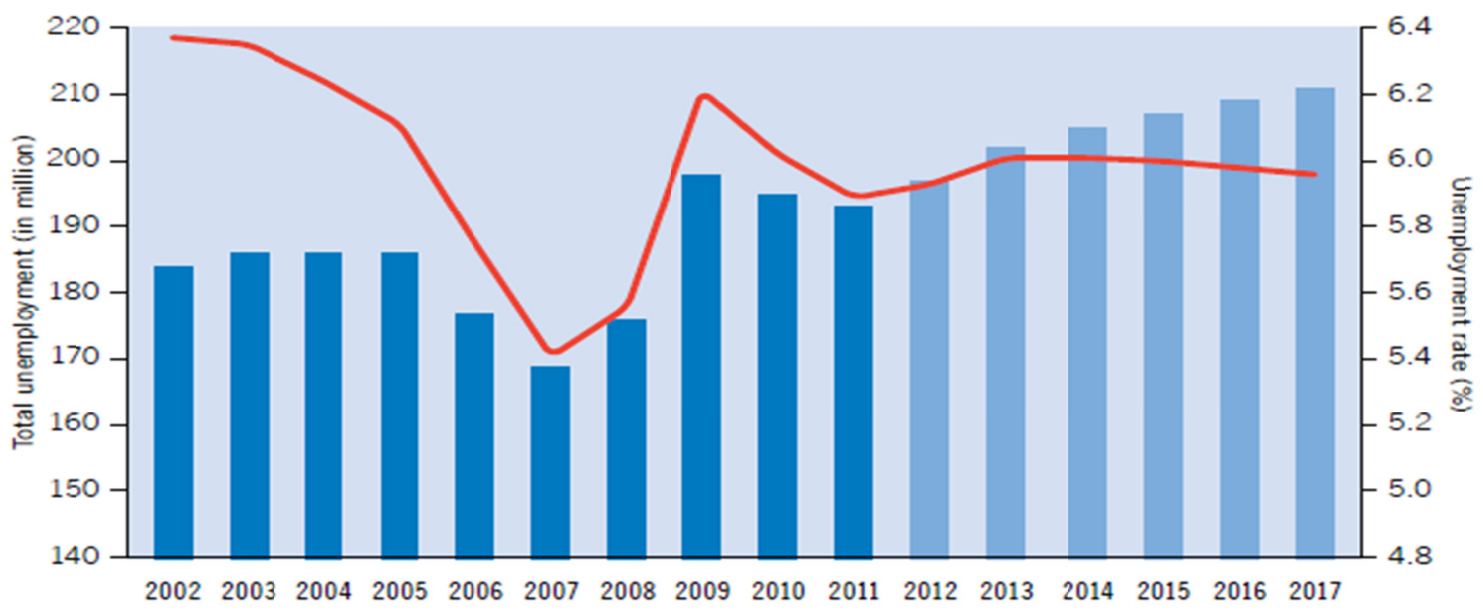

Figure 9. Global unemployment trends and projections, 2002-17

Source: ILO. 2013. "Global Employment Trends-2013”.

Labour income taxes and social contributions may lead to increase long run employment level. Moreover, labour income taxes have a direct impact on the supply of marginal groups of workers (women, unskilled and older workers 
etc.) by making labour participation more attractive. Tax wedges can also affect labour demand through negative substitution effects on working hours and employed workers. In practice, the theory of "employment protection" legislations (EPL) may enhance productivity by providing insurance to protect job security. In addition, this may lead to reduce labour turnover movements and increase flexibility, as skilled workforce is willing to provide training to other workers. By contrast, if EPL rules are not well designed, unemployed workers may reduce job search efforts (Giuseppe Nicoletti and Stefano Scarpetta, 2005). Equilibrium level of employment rises with highly bargained wage rates.

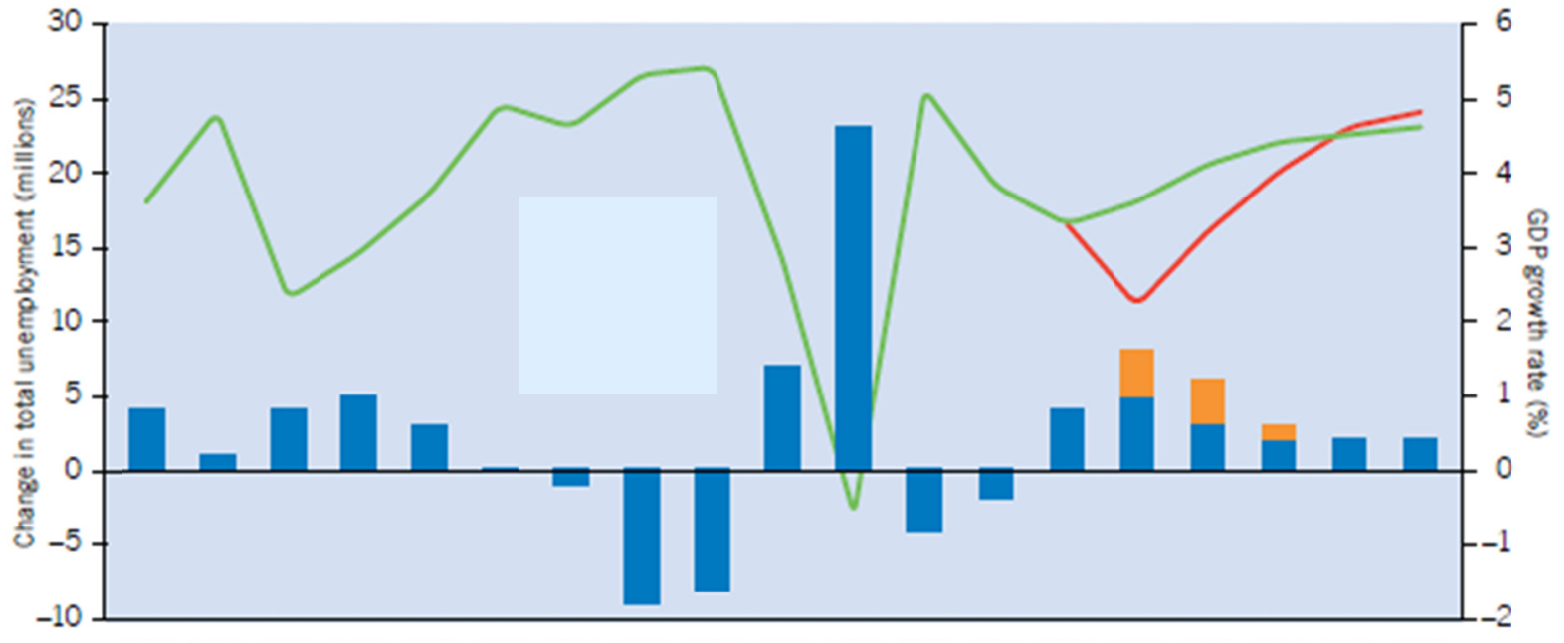

1999200020012002200320042005200620072008200920102011201220132014201520162017

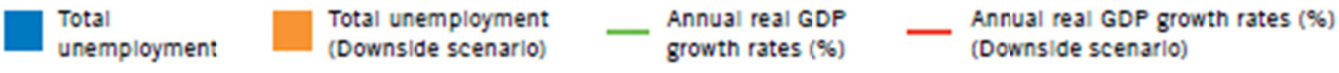

Figure 10. Annual change in global unemployment and GDP growth, 1999-201

Source: ILO. 2013. "Global Employment Trends-2013".

Product market reforms aim to improve competitiveness and reduce barriers to international trade and investment. These reforms should have a positive impact on allocative efficiency and competition by providing incentives for firms to the adoption of new technologies. This means that inputs and outputs are allocated more efficiently which in turn lower costs, and that the prices are more in line with marginal costs. In addition, the reform performance differs across industries and countries. Many studies have highlighted two main effects of reform: i) the process of privatization and ii) the process liberalization both of which are correlated with productivity gains (Rachel Griffith and Rupert Harrison, 2003). Regulatory policies generally concern about market failures such as asymmetric information and externalities. Product market reforms with labour market reforms lead to rise in employment level which in turn lead to accelerate the growth rate.

\subsection{Regulatory Reforms}

Over the decade, changes in structure of financial intermediation have eased access to finance by advances in information technology and contributed to economic growth, but brought new risks in markets. The Regulatory Reforms are aimed at reducing the burden of financial distress and making financial system safer, more transparent, less complex and less leveraged. Most reforms focus on the banking sector to internalize costs of the certain risky activities within the financial system but this is not an easy task. Stijn Classens and Eric Feijen (2006) highlight the importance of the economies of scale and the outreach of financial system. They suggest that large scaled financial system can lead to improve credit infrastructure and existing networks can be used to expand its outreach. Additionally, reducing government regulation to a minimum level is necessary to enhance competition in the financial system. Andy Summer and Meera Tivari (2010) find that that the access to financial services should be improved to reduce poor households and small size of firms. They provide new evidence of a positive association between financial sector development and the millennium development goals; health, education, gender equality, and income poverty as summarized in Figure 11.

The intervention measures are needed to support the real economy and are also aimed at preventing a collapse of the financial system in some countries. Although the reforms help construct a safer financial structure, too important to 
fail issues are still unresolved, and highly integrated economies are susceptible to harmful spill over effects (IMF, 2012). Regulations imply that there is risk in some large institutions and the costs became riskier than originally envisaged during the crisis, (IMF, 2012). Hence, the reform agenda should aim to achieve the following goals:

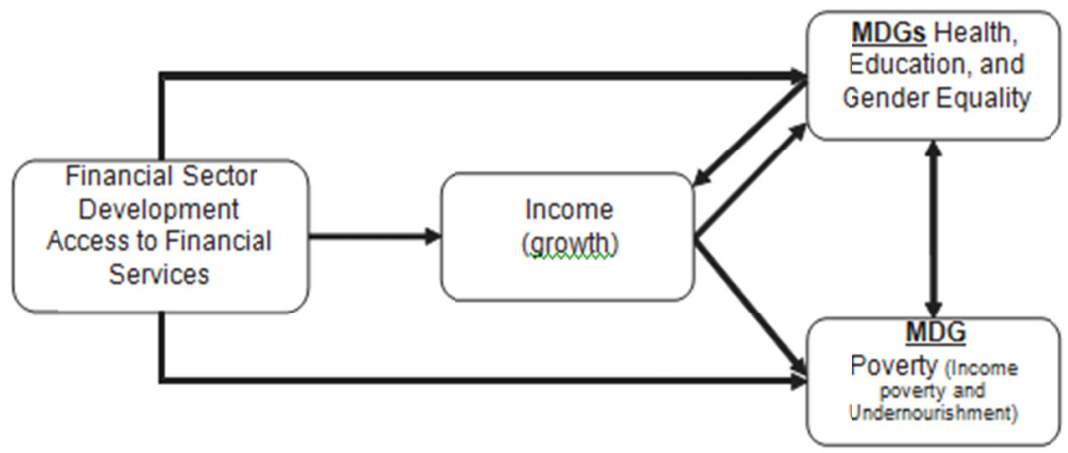

Figure 11. Relationships between financial sector development, income and the MDGs

Source: Stijn and Feijen. 2006. "Financial Sector Development and the Millenium Development Goals".

- A more transparent and less complex financial system so that the risks can be properly priced by investors.

- A financial system with less leverage, and hence less prone to boom and bust cycles with positive aspects of globalization while limiting contagion risks (risk diversification and access to finance).

- Higher and better quality capital and liquidity requirements that reflect the systemic risks. As a result, there may be a migration of non-traditional activities to the nonbanking sector. If that will be the case, then greater attention to regulation and reform standards in the nonbanking financial sector will be required (IMF, 2012).

- Monitoring the financial system for a better understanding and oversight of risks in the nonbank financial institutions.

A well-developed financial sector screens and monitors both potential investors and users of capital and also produces information. If financial institutions screen borrowers effectively and produce new information about firms, then this is a first step in expanding productivity growth. Furthermore, if financial institutions monitor the investment after the financial transaction occurs, this encourages the operational efficiency and economic activity. Thus, finance affects the quantity of investment and the efficiency of capital allocation (Levine, 2011).

European policy makers also announced further policy measures aimed at fragmentation of Euro-zone financial markets and strengthening the European Monetary Union (EMU). Restructuring the European Stability Mechanism (ESM) to recapitalize sovereign banks as a single supervisory mechanism and restating commitment to use ESM for stabilising secondary sovereign bond markets are some significant steps towards preventing the spread of crisis. The ESM was created as the main instrument for providing financial assistance and financing new programmes for euro-area member states in October, 2010. This mechanism is expected to have 700 billion euro capital reserves at the first half of 2014. The member states will make payments commensurate to their GDP levels periodically until the amount of capital reserves completed. In May 2010, the European Central Bank (ECB) introduced the Securities Markets Programme (SMP) in order to intervene on secondary market segments that hampered the monetary policy transmission mechanism. The programme was terminated in September 2012. On September 6, 2010, the ECB announced its "Outright Monetary Transactions Program" (OMTs) as a replacement for the Securities Markets Programme. Under the OMTs, the ECB aims to preserve the singleness monetary policy across euro-area. In addition, OMT has five important features including European Financial Stability Facility (EFSF) mechanism, ESM program, mode of intervention, ranking of claim, transparency, and the collateral policy. EFSF was created as a temporary rescue mechanism by providing financial assistance to euro area member states in October, 2010. As of 1 July 2013, the EFSF may no longer intervene in the bond markets or engage in new financing programmes. The ESM is now the permanent and main mechanism for financial stability. The ECB will assist countries through EFSF/ESM and help ensure that low policy rates transmit to low borrowing costs in the peripheral Euro zone (IMF, 2012).

The Euro-zone sovereign debt crisis has highlighted the importance of having a framework to eliminate weaknesses of sovereign banks and strengthen the EMU. For this reason, European Commission published its proposals to create 
the "European Banking Union" (EBU) within the Euro area. The EU Commission reached the political agreement on the "Single Supervisory Mechanism" (SSM), the "Single Resolution Mechanism" (SRM) and a common deposit insurance system as the three pillars of EBU. The main role of the SSM as an independent supervisor is to restore confidence in the banking sector. The SRM produces timely solutions to prevent spill over problems from one bank to another. Finally the last pillar, common deposit protection would lower the probability of bank runs as it reduces the deposit withdrawals.

The reforms in some areas still need to be further refined by policy makers. The success of the reforms depends on enhanced supervision, political will to implement regulations, recovery and reform plans for making the financial system safer (IMF, 2012). At the end, regulatory reforms and macroeconomic policies are necessary for a safer financial system to achieve sustainable growth. An important theme is that an appropriate institutional structure is critical for preventing financial crises.

\section{Conclusion}

Recent years, world economy has been shaken by several crises, because of both uncertainties and unexpected shocks to financial structure. After the recent financial crisis, two main structural changes took place in the financial system. First, institutional investors became major players in providing long-term capital with at least five year maturity and alternative source of financing. Second, now the banking model is more dominated in derivatives trading instead of its traditional deposit-lending activities. To that end, increasing volatility in global financial markets diverted the attention to even some monetary policy actions (IMF, 2013).

The recent financial crisis shows that the immediate economic reforms and macroeconomic programmes should be implemented by policy makers. Two pillars of economic reforms, labour market reforms and product market reforms, should address the need for fiscal consolidation and improvement in public finance. In this circumstance, Central Bank Governors and Finance Ministers need to pay greater attention to economic reforms and macro policies to stimulate recovery in economies. Redesigning the financial system with the support of economic reforms and macro policies can help accelerate the rate of economic growth and reduce financial distress.

Policy makers must also take regulatory actions to restructure weak banks to improve transparency, effectiveness of exchange of information and risk management. Bank regulatory reforms are also needed to reduce ongoing risks to global financial stability. As such, financial sector development has to be an important tool to decline possible market risks. The further reform process should address weak bank balance sheet repair to credit channel. Thus, regulatory financial policies will help the transmission of monetary policy.

The limitation to this study is that the topic of the paper is time based. In other words, the economic reforms, regulatory actions and policy implications suggested in this paper may be time-specific. As the new conditions arise through time, suggested actions may be no more suitable to cope with the crisis. It is also noteworthy that the conclusions drawn in this study may be suitable for only the current global crisis. Although the crises may have some commonalities, every crisis has its own characteristics and therefore should be handled uniquely. From this perspective, the results in this study should not be taken as the only and general way of dealing with crises.

\section{Acknowledgement}

The authors thank seminar participants at Mediterranean Research and Observatory of Yaşar University for comments on an earlier version of this paper.

\section{References}

Aghion, P., Howitt, P., \& Mayer-Foulkes, D. (2005). The Effect of Financial Development on Convergence: Theory and Evidence. The Quarterly Journal of Economics, 120, 173-222. http://dx.doi.org/10.1162/0033553053327515

Akerlof, G. A. (2002). Behavioral Macroeconomics and Macroeconomic Behavior. The American Economic Review, 92, 411-433. http://dx.doi.org/10.1257/00028280260136192

Andrade, J. S., \& Duarte, A. (2011). The Fundamentals of the Portuguese Crisis. Panoeconomicus, 58, 195-218. http://dx.doi.org/10.2298/PAN1102195A

Antzoulatos, A. A. (2012). Policy Responses to the European Debt Crisis Treating the "Symptoms" or the “Disease?". Panoeconomicus, 59, 529-552. http://dx.doi.org/10.2298/PAN1205529A

Arcand, J.-L., Berkes, E., \& Panizza, U. (2012). Too much Finance, IMF Working Paper 12/161. 
Beck, T. (2012). The Role of Finance in Economic Development - Benefits, Risks, and Politics, Dennis Müller (Ed.). Oxford Handbook of Capitalism.

Beck, T., Levine, R., \& Loayza V.N. (2000). Finance and the Sources of Growth. Journal of Financial Economics, 58, 261-300. http://dx.doi.org/10.1016/S0304-405X(00)00072-6

Bolton, P., \& Jeanne O. (2011). Sovereign Default Risk and Bank Fragility in Financial Integrated Economies. NBER Working Paper Series No:16899.

Brealey, R., Myers, S., \& Marcus A. (2009). Fundamentals of Corporate Finance (Sixth ed.). McGraw- Hill.

British Broadcasting Corporation (BBC) News. (2011). Eurozone debt web: Who owes what to whom?, Retrieved August 25, 2013, from http://www.bbc.co.uk/news/business-15748696

Campbell, J., Lettau M., Malkiel, B., \& Xu Y. (2001). Have Individual Stocks Become More Volatile? An Empirical Exploration of Idiosyncratic Risk. Journal of Finance, 56, 1-43, http://dx.doi.org/10.1111/0022-1082.00318

Classens, S., \& Feijen, E. (2006). Financial Sector Development and the Millennium Development Goals. World Bank Working Paper No.89. http://dx.doi.org/10.1596/978-0-8213-6864-0

European Central Bank (ECB). (2013). Financial Structure, Retrieved September, 10, 2013, from http://www.ecb.europa.eu/mopo/eaec/structure/html/index.en.html

European Comission (EC). (2013). Retrieved September, 14, 2013, from http://ec.europa.eu/commission_2010-2014/president/g20/index en.htm

Ferreiro, J., Gomez, C., \& Serrano. F. (2013). Mistakes in the Fiscal Policy in Spain before the Crisis Panoeconomicus. Panoeconomicus, 60, 577-592. http://dx.doi.org/10.2298/PAN1305577F

Giavazzi, F., \& Spaventa. L. (2010). Why The Current Account Matters in A Monetary Union: Lessons From The Financial Crisis in The Euro Area. The Euro Area and the Financial Crisis, Bratislava. http://dx.doi.org/10.1017/CBO9781139044554.015

Gomez-Puig, M., \& Sosvilla-Rivero, S. (2011). Causality and Contagion in Peripherial Emu Public Debt Markets a Dynamic Approach. Research Institute of Applied Economics Working Paper No:201. http://dx.doi.org/10.2139/ssrn.1932378

Griffith, R., \& Harrison, R. (2003). The Link Between Product Market Reforms and Macro-economic Performance. http://dx.doi.org/10.1920/wp.ifs.2006.0606

Group of Twenty (G-20). (2011). Communiqué of Finance Ministers and Central Bank Governors of the G20: Paris-France, 14-15 October 2011.

Horowitz, S., \& Heo. U. (2001). The Political Economy of International Financial Crisis: Interest Groups, Ideologies and Institutions. Rowman and Littlefield Publishers, Boston.

International Labour Organization (ILO). (2010). World of Work Report: From one crisis to the next?

International Labour Organization (ILO). (2011). Building a Sustainable Job-Rich Recovery. International Institute for Labour Studies.

International Labour Organization (ILO). (2012). World of Work Report 2012: Better jobs for a better economy.

International Labour Organization (ILO). (2013). Global Employment Trends-2013. International Institute for Labour Studies.

International Monetary Fund (IMF). (2012). Global Financial Stability Report: Restoring Confidence and Progressing on Reforms. World Economic and Financial Surveys.

International Monetary Fund (IMF). (2012). Global Recovery Stalls, Downside Risks Intensify. World Economic Outlook Update.

International Monetary Fund (IMF). (2012). Coping with High Debt and Sluggish Growth. World Economic Outlook.

International Monetary Fund (IMF). (2013). World Economic Outlook 2013: Hopes, Realities, Risks. World Economic and Financial Survey.

Janus, T., \& \& Riera-Crichton, D. (2012). Banking Crises, External Turmoil and the Role of Gross Foreign Investment Reversals. 
Kindleberger, C. P. (2005). Manias, Panics and Crashes: A History of Financial Crises. John Wiley \& Sons.

Krugman, P. (1999). Balance Sheets, the Transfer Problem and Financial Crises. International Tax and Public Finance, 6, 459-472. http://dx.doi.org/10.1023/A:1008741113074

Levine, R. (2005). Finance and Growth: Theory and Evidence. In Aghion, P. and Durlauf S. (Eds.), Hand Book of Economic Growth (pp. 865-934). Amsterdam Elsevier.

Levine, R. (2011). Finance Regulation and Inclusive Growth. OECD and WB Conference-France, Challenges and Policies for Promoting Inclusive Growth. http://dx.doi.org/10.1787/9789264168305-4-en

Levine, R. (2012). The Governance of Financial Regulation: Reform Lessons from the Recent Crisis. International Review of Finance, 12, 39-56. http://dx.doi.org/10.1111/j.1468-2443.2011.01133.x

Levine, R., Loayza, N., \& Beck, T. (2000). Financial Intermediation and Growth: Causality and Causes. Journal of Monetary Economics, 46, 31-77. http://dx.doi.org/10.1016/S0304-3932(00)00017-9

Lin, J. Y., \& Treichel, V. (2012). The Crisis in the Euro Zone: Did the Euro Contribute to the Evolution of the Crisis?, World Bank Policy Research Working Paper 6127. http://dx.doi.org/10.1596/1813-9450-6127

Madura, J. (2006). Financial Markets and Institutions, 7e, South-Western.

Megginson, W. L. (1997). Corporate Finance Theory. Addison-Wesley Longman.

Minsky, H. P. (1992). The Financial Instability Hypothesis. The Jeroey Levy Economics InstituteWorking Paper No:74. Prepared for Handbook of Radical Political Economy. http://dx.doi.org/10.2139/ssrn.161024

Mishkin, F. S. (1990). Asymmetric Information and Financial Crises: A Historical Perspective. NBER Working Paper Series No:3400.

Mishkin, F. S. (1992). Anatomy of a Financial Crisis. Evolutionary Economics, 2, 115-130. http://dx.doi.org/10.1007/BF01193536

Mishkin, F. S. (1996). Understanding Financial Crises: A Developing Country Perspective, NBER Working Paper-5600.

Mishkin, F. S. (1999). The Lessons from The Asian Crisis. Journal of International Money and Finance, 18, 709-723. http://dx.doi.org/10.1016/S0261-5606(99)00020-0

Mishkin, F. S. (2001). Financial Policies and the Prevention of Financial Crises in Emerging Market Economies. NBER Working Paper-8087. http://dx.doi.org/10.1596/1813-9450-2683

Mishkin, F. S. (2006). The Economics of Money, Banking, and Financial Markets. 7e, Pearson.

Nicoletti, G., \& Scarpetta, S. (2005). Product Markets Reforms and Employment in OECD Countries. OECD Economic Department Working Papers, No:472.

Organisation for Economic Co-operation and Development (OECD). (2012). Fiscal Consolidation: How much, how fast and by what means? OECD Economic Policy Papers. No:01.

Rioja, F., \& Valev, N. (2004). Does One Size Fit All? A Re-examination of the Finance and Growth Relationship. Journal of Development Economics, 74, 429-447. http://dx.doi.org/10.1016/j.jdeveco.2003.06.006

Sunmer, A., \& Tivari. M. (2010). Global Poverty Reduction to 2015 and Beyond: What has been the Impact of the MDGs and What are the Options for a Post-2015 Global Framework?. IDS Working Paper 348. http://dx.doi.org/10.1111/j.2040-0209.2010.00348_2.x

Umutlu, M, Akdeniz, L., \& Altay-Salih, A. (2010). The Degree of Financial Liberalization and Aggregated Stock-Return Volatility in Emerging Markets. Journal of Banking and Finance, 34, 509-521. http://dx.doi.org/10.1016/j.jbankfin.2009.08.010

Umutlu, M., Akdeniz, L., \& Altay-Salih, A. (2013). Foreign Equity Trading and Average Stock-Return Volatility. The World Economy, 36, 1209-1228. http://dx.doi.org/10.1111/twec.12011

World Bank (WB). (2013). Less Volatile but Slower Growth, Global Economic Prospects, 7. 